\title{
Assessment of the Implementation of Social Studies Curriculum in Junior Secondary Schools in Osun State, Nigeria
}

\author{
A. J. Obadiora (Ph.D) \\ Department of Arts and Social Science Education \\ Obafemi Awolowo University, Ile-Ife, Nigeria
}

The research is financed by the researcher

\section{Abstract}

This study was carried out to investigate the implementation process of Social Studies curriculum in Osun State Nigeria. The descriptive survey design was adopted for the study. The study sample consisted of 259 teachers. Two instruments were used for the study namely (1) Questionnaire on Teacher of Social Studies' Quantity and Quality (QSTQQ) and (2) Social Studies Instructional Strategies and Materials Observation Check List (SISMOCL). The study was carried out in nine weeks. Data collected were analysed using simple percentage. The results showed that the implementation process of Social Studies curriculum is lacking some basic and necessary elements (such as trained teachers, suitable strategies and appropriate instructional materials) in terms of quantity and quality. The study concluded that Social Studies has not been well implemented in Osun State Nigeria. It was recommended that all stakeholders including government, proprietors of private secondary schools, philanthropists, parents among others should see to the provision of adequate number of trained teachers, the use of appropriate instructional materials and strategies for the implementation of social studies curriculum in secondary school in the state.

Keywords: Assessment; Implementation; Curriculum; Trained Teachers, Instructional Strategies; Instructional Resources.

DOI: $10.7176 / \mathrm{JEP} / 10-32-06$

Publication date: November $30^{\text {th }} 2019$

\section{Introduction}

Nigeria is a nation of many ethnic groups amalgamated and colonized by the British Government in the nineteenth and twentieth centuries. After its independent in 1960 there was no evidence of Nigerian as a nation in that each region mistrusted its neighbour. Political leaders at that time did not help to establish cordial relationship among the existing various ethnic groups hence the outbreak of 1967 Nigeria civil war (Omolewa, 1986). The most important need of the society after the civil war was how to unite the different ethnic groups of the country. This opinion justifies the introduction of the 3Rs (Reconstruction, Rehabilitation and Reconciliation) policies embarked upon by the Gowon regime. One of the major tools identified to achieve the 3Rs was education. The type of education that can make people forget the negative experience of the past, promote cultural and religious tolerance as well as foster equality, peace, and justice among the people.

Coincidentally, it was at that period that African scholars and elites were desperately agitating for restructuring in the education system of the African countries. This led to the Mombassa social studies conference of 1968 which was attended by eleven African countries, including Nigeria. The conference emphasized the urgent necessity for education in Africa to relate specifically to the need and culture of Africans through Social Studies. In pursuance of the resolution, the conference came up with a social studies curriculum which was accepted by all for adoption to suit the individual needs of participating countries (Akinlaye, 1981). The resolution also led to the Nigerian National Curriculum Conference of 1969, organized by Nigeria Educational Research Council (NERC) at Lagos. The conference came up with the adoption of the National Policy on Education (NPE) which was first published in 1977 (Fedral Ministry of Education, 2003). The important feature of the policy was its outline of a philosophy for Nigerian education which included the development of the individual into sound and effective citizen. It also included full integration of the individual into the community, provision of equal access to educational opportunities for all citizens of the country and consideration of a number of subjects that can help to achieve the design (Federal Republic of Nigeria, 2004).

One of the subjects of prime importance considered was Social Studies. The term Social Studies denote an integrated and unified subject that attempts to examine and improve upon the political, socio-cultural, religious and economic life of the people. The acceptance and introduction of Social Studies as a curriculum subject in the Nigerian education sector at that particular time was very pertinent because of the enormity of the socio-political problems which almost led to the disintegration of the country. Ikwumelu, Bassey and Oyibe (2015) agreed that Nigeria being a pluralistic society was faced with the challenge of conflicting values. In view of this, Social Studies as a subject full of values and virtues instructions is saddled with the task of sustaining peaceful coexistence of the Nigerian people.

Social studies curriculum provides a vital forum for developing the thinking, skills as well as the values and 
attitudes that make the 'good citizen' and equip him/her for coping with change. As a product of social studies education, a good citizen should possess good orientation and positive attitude toward other people's culture and religious beliefs. Despite the relevance of Social Studies and its teaching for over 40 years as one of the compulsory subjects designed to solve socio-political problems in Nigeria, it has been realised that Nigerian children and youth are still involved in causing socio-political, cultural and religious crises in the country. As a matter of fact the levels of crime and crises in the Nigerian society do not show that majority of these children and youth have been exposed to a core subject like Social Studies which has the focus of producing a good citizen. Nigerian secondary school social studies curriculum is a well designed programme with provision for adequate contents, performance objectives and recommended instructional strategies. It suggests activities for teachers and learners and recommends appropriate instructional materials to exert influence and bring positive change in the learners. It also contain evaluation guide to assess learner's level of achievement at every stage of the teaching and learning process in social studies class. But it is not certain whether stakeholders are faithfully committed to the implementation of the curriculum.

Scholars have carried out several studies to assess social studies programme implementation both at national and international levels. At international level Marsh (1987) investigated the implementation of a social studies curriculum in an Australian Elementary School majorly to determine the extent to which the faculty members were knowledgeable about teaching the curriculum. In Nigeria similar study was carried out by Aliyu (2009) on the assessment of the implementation of social studies curriculum in primary schools in Kano Metropolis. The study focused on the differences in the opinion of primary school teachers of Social Studies, the extent of utilization of the inquiry approach in the classroom, the availability of curriculum materials for teaching Social Studies and difference in the influence of pupils' age on their awareness of useful social values in the society. Umudi (2012) examined importance of content implementation in junior secondary school Social Studies. This involves considering what the teachers and learners should pay attention to during teaching and learning situation. Also, Ebiere and Adediran (2013) worked on the quality assurance of teachers in the assessment of social studies curriculum of secondary schools in Abeokuta Metropolis in Ogun State, Nigeria. The study was limited to the quality of teachers in the assessment of the social studies curriculum implementation in secondary schools in the study area. Therefore, it could be ascertained that a number of scholars have assessed different aspects of social studies curriculum implementation process separately but a more holistic approach to the assessment of the curriculum is needed especially in Osun State where reports of such investigation are not readily available, hence this study.

\subsection{Objective of the Study}

The objectives of the study are to:

a. examine the quantity and quality of teachers teaching Social Studies in the secondary schools in Osun State Nigeria;

b. assess the instructional strategies used in teaching Social Studies in the State; and

c. examine the availability of instructional materials used in teaching the subject in the study area.

\subsection{Research Questions}

From the objectives of the study the following questions were asked:

a. How available are the teachers of Social Studies in secondary schools in Osun State?

b. How qualify are the teachers of Social Studies in secondary schools in the State?

c. To what extent are the teachers of Social Studies in Osun State using recommended instructional strategies?

d. How suitable are the instructional strategies that teacher of Social Studies used in teaching Social Studies in the study area?

e. How available are the instructional materials used in teaching Social Studies in secondary schools in the State?

\subsection{Assessment Model}

Assessment is an integral part of every education programme. Ehindero (1986) put forward that assessment is a measure of attainment which provides input for modification. It is a criterion for the establishment of the accomplishment of a process, project, course or programme. It could be seen as a fraction of evaluation. Every stage of a useful education programme needs to be examined. For this purpose Stufflebeam developed a framework in late 1960s in the United State of America. This framework is known as Stufflebeam's Context, Input, Process, and Product (CIPP) evaluation model. It is a model for conducting formative and summative evaluations of projects (Stufflebeam \& Shinkfield, 2007). Each of the four components (Context, Input, Process, and Product) of Stufflebeam's model assesses different stage of a given education programme.

The context sphere of CIPP evaluation model often referred to as needs assessment and helps assess 
problems, assets and opportunities within a defined community. The input evaluation component helps prescribe a responsive project that can best address the identified needs. Also the process evaluation component monitors the project procedural barriers, and identifies needs for project adjustments. While the product evaluation component measures, interprets, and judges project outcomes and interprets their merit, worth, significance, and probity (Stufflebeam \& Shinkfield, 2007). In education sectors, the CIPP evaluation model has been found to be useful in measuring the achievement and value of educational programmes (Zhang, Zeller, Griffith, Metcalf, Williams, Shea, \& Misulis, 2011). Thus, it was considered for the holistic assessment of the implementation of social studies curriculum in Osun State, Nigeria as presented in this study.

Prior to the introduction of social studies education in Nigeria, the situation and the needs of the Nigerian society were clearly identified. The nation goals were evidently highlighted, education was considered as the major tool to be used to meet the needs of the society and the nation educational objectives were written in line with the nation general goals. As a result, Nigerian Government through Nigerian Educational Research Council (NERC) (now Nigerian Educational Research and Development Council, NERDC), the Comparative Education Study and Adaptation Centre (CESAC) embraced the social studies education project sponsored by the Ford Foundation of America and the United States Agency for International Aid (USAID). The project was carried out by the Ohio University in the Comprehensive High School, Aiyetoro, Egbado Nigeria. The social studies education programme designed was scrutinised, field tested and evaluated at every stage of the development. The project results' dissemination led to the acceptance of Social Studies as a useful subject in all the states of the federation and this marked the beginning of social studies curriculum implementation in Nigeria (Adewuya, 1992).

Programme is designed and developed to be implemented for the benefit of the society for which it was developed. The value and beauty of a programme is appreciated when the programme is being implemented. Implementation is the process of carrying out of a programme according to the prescribed rules. Implementing a curriculum has to do with the process of executing the design as described and prescribed by the curriculum toward the attainment of a particular objective. The most important thing is that the implementation must follow rules presented in the document, the way it was intended to be implemented by the developers. This is what National Centre on Early Childhood Development, Teaching and Learning (NCECDTL, 2011) called implementation fidelity. According to NCECDTL, assessors of curriculum implementation should be concerned about whether qualified staff was used, whether staff focused on the specific goals identified in the lesson plans, whether staff used the recommended teaching strategies, or whether staff used recommended and appropriate instructional materials. This necessitates the use of professional staff in the implementation of curriculum. Professional teachers have received professional training and gained appropriate knowledge, skills, techniques, and attitudes necessary for discharging their duties. The United Nations Educational, Scientific and Cultural Organization (UNESCO, 2004) opined that the trained teachers' are more competent and such play unique role in the implementation of the curriculum toward achieving the curriculum ultimate objectives.

Professional teacher could adjust instruction with the use of various instructional strategies according to the dictate of the subject matter, class size, instructional objectives and the interest of the learner as a motivation to learners' learning. In line with this Gupta (2000) stated that good teaching involves deciding on the course content, preparation and presentation of the subject in an interesting and interactive manner and keeping learners motivated. Muna (2006) described, the eclectic approach of combining several strategies including child-centred learning as contains more benefits for both the learner and the teacher. An analysis that synthesized finding from a group of studies by Greensward, Hedges and Laine (1996) showed that teachers with pedagogical training performed better than those who entered teaching without such training.

As educational qualification and experience enrich professional skills of a qualified teacher to identify and choose appropriate teaching strategies for different situations likewise it does to the teacher's choice of instructional materials. Instructional materials are the human and material objects which teachers use to make lesson interesting to the learners. They are of a great value to the effective implementation of curriculum. They pave way for more participation of the learners both physically and intellectually. Instructional materials stimulate interest and help to make lesson more practical when learners actually see the objects being discussed and are capable of providing knowledge of things outside children's experience especially when shown in still or motion pictures. The teaching of Social Studies can be made meaningful through the use of instructional materials (SAGLAM, 2011). Also, according to Ogbondah (2008) there is a significant relationship between the available instructional materials and effective curriculum implementation. It is only a well implemented programme that can bring about an expected result.

\section{METHODOLOGY}

The study adopted the descriptive survey design. The population for the study comprised teachers of social studies in junior secondary schools in Osun State, Nigeria. The study sample consisted of 259 teachers. Three local government areas were selected from each of the three Senatorial Districts in Osun State. From each of the 
selected three Local Government Areas 30 schools (15 each of public and private) were selected using stratified random sampling technique making a total number of 270 schools. Total enumeration sampling technique was used to select 259 teachers that were available in all the selected 270 schools. Two instruments were used for the study namely (1) Questionnaire on teachers of Social Studies' Quantity and Quality (QSTQQ) and (2) Social Studies Instructional Strategies and Material Observation Check List (SISMOCL). These instruments were designed by the researcher. The content and face validity of the instruments were done by experts in the field of Social Studies and Test and Measurements in Obafemi Awolowo University Ile-Ife. The study was carried out in nine weeks. The researcher and the research assistants spent three weeks in each Local Government Area to administer the research instruments. Each of the selected teachers of Social Studies was observed three different times during the Social Studies lessons. Data collected were analysed using simple percentage.

\section{RESULTS AND DISCUSSION}

\subsection{Research Question One A}

How available are the teachers of Social Studies in secondary schools in Osun State?

To answer this question data collected on the availability of the teacher of Social Studies in Osun State secondary schools were analysed. The essence of this analysis is to examine whether teachers of Social Studies are adequately available in Osun State secondary schools as stipulated by the Nigeria National Policy on Education. The results are as presented in table 1. The table showed that out of 135 public secondary schools selected $126(93.33 \%)$ schools have teachers teaching Social Studies and out of the 135 selected private secondary schools $133(98.52 \%)$ schools have teachers teaching Social Studies. Although, the data showed that Social Studies is taught in many of the selected schools as a curriculum subject but not with adequate number of teachers. The Nigerian Educational Research and Development Council recommended that a teacher should not teach more than 40 students in a class/school per subject at secondary school level (1:40 teacher-learner ratio) as stipulated in section 5 subsection 25 of the Nigerian National Policy on Education (FRN, 2004). However, in Osun State many teachers of Social Studies teach more than 40 students. Majority of the selected schools have only one teacher to teach Social Studies at the three junior secondary school levels (JS I-III). It is in few junior secondary schools where population of students are very low that teachers of Social Studies are not teaching more than the stipulated number (40) of students. Therefore, the results of this investigation showed inadequate availability of the teachers of Social Studies in secondary schools in Osun State.

This finding is in line with the report of UNESCO (2006) that some nations of the world are facing the problem of teacher's shortage. Also, the results corroborate the observation of Subair and Talabi (2015) that the teachers available in Nigerian secondary schools are below the number needed for efficiency in the delivery of instructions. The results of this study also support the report of International Labour Organization (2016) that the teacher numbers within and across countries in Africa indicates that the employment and deployment of teachers is neither efficient nor equitable. Inadequate number of teachers may results to excess workload for the available few. Teacher can be deficient if they are saddled with too much of responsibilities and this could lead to poor academic performance of learners.

\subsection{Research Question One B}

How qualify are the teachers of Social Studies in secondary schools in Osun State?

To answer this question data collected on the qualification of the teachers of Social Studies in Osun State secondary school were analysed. The essence of this analysis is to examine whether those who are teaching Social Studies in Osun State secondary schools are qualified to do so as stipulated in section 8 subsection $70 \mathrm{~b}$ of the Nigeria National Policy on Education that the minimum qualification for entery into the teaching profession shall be the National Certificate in Education (FRN, 2004). The results of the investigation are as presented in table 2. The table showed that there are various categories of teachers being used in secondary schools in Osun State to teach Social Studies such as teachers in the field of Social Studies with National Certificate in Education (NCE), Bachelor Degree (B.Ed., B.A.Ed, \& B.ScEd), Masters Degree (M.Ed. \& M.AEd.,) and Doctoral Degree (Ph.D) and outside the field of Social Studies NCE, Bachelor Degree (B.Ed., B.A., \& B.Sc) and Masters Degree (M.Ed., \& M.A.Ed). There are those outside the field of education from polytechnic and university (Humanities and Sciences) with Ordinary National Diploma certificate (OND), Higher National Diploma certificate (HND), Bachelor Degree (B.A. \& B.Sc) and Masters Degree ( M,A. \& M.Sc). Others include members of the Nigerian Youth Service Corps (NYSC) and Nigerian youth on empowerment scheme (NPOWER) with and without background in the field of education. Majority of these categories of teachers are not trained teachers especially in the field of Social Studies and are not qualified to teach the subject. Table 2 also showed that the percentage of qualified teachers in the selected schools (public $49.21 \%$, private $27.07 \%$ ) are less than the percentage of unqualified teachers (public $50.79 \%$, private $72.93 \%$ ) in the schools.

The results showed that majority of those who are teaching Social Studies in Osun State are not specialists trained to teach the subject. These results confirmed the finding of Usulor (2014) that most teachers that teach 
Social Studies are not qualified because they are not specialists in the of Social Studies. In line with the findings of this study, Adeyemi (2009) has observed that the supply did not match the demand for qualified teachers in secondary schools in Ekiti State. Also Symeonidis (2015) reported that hiring of unqualified teachers is very common in African schools.

The use of untrained teachers in teaching Social Studies cannot help the society to achieve the objectives for which the subject was developed. These untrained teachers lack adequate knowledge of Social Studies and the rationale for the introduction of the subject. They do not share the vision of the subject and may not be able to teach it with passion. In the process of carrying out this study it was realized that the untrained teachers are teaching for salary not because they are interested in guiding learners to construct the right meaning and imbibe the right values.

\subsection{Research Question Two A}

To what extent are the teachers of Social Studies in Osun State using recommended instructional strategies? To answer this question data collected on the use of recommended instructional strategies were analysed. The essence of this analysis is to assess the use of recommended strategies in teaching Social Studies as presented by NERDC in the social studies curriculum. The results are as presented in table 3. The table showed some recommended instructional strategies and the percentage of teachers that used them in public and private secondary schools in Osun State. From the table 100\% of the teachers teaching Social Studies in the selected public secondary schools used expository strategy. Other strategies used are as follows: questioning strategy $45.24 \%$, inquiry $27.2 \%$, combination of two or more strategies $24.6 \%$, demonstration strategy $6.34 \%$ while $3.96 \%$ used lecturing, play way and dramatization strategies. The table also showed that $100 \%$ of private school teachers used expository strategy to teach Social Studies, 48.87\% used questioning strategy. Also 32.33\% used demonstration strategy, $15.79 \%$ used inquiry strategy, $7.52 \%$ used field trip while $2.26 \%$ used resource person and combination of two or more strategies. Ukadike and Iyamu (2007) put forward that the expository method used by teachers of Social Studies is responsible for the poor implementation of the social studies curriculum in Nigeria.

The use of recommended instructional strategies demands the awareness of such recommendations. Guilfoile and Delander (2014) affirmed that for many teachers common methods are used as method of instruction. It has been realised that some teachers are not aware of the information that there are recommended instructional strategies for teaching different content of Social Studies. This may be due to the fact that such teachers are not trained in the field of Social Studies, they do not know whether there is anything called curriculum but only exposed to the use of syllabus and scheme of work for writing lesson notes. Also social studies curriculum is not available in some of the secondary schools in the State and where they are available they are kept with the principal/head teacher of the schools and not being used by the teachers for lesson preparation. Therefore, it is very difficult for the teachers to make use of the recommended instructional strategies as suggested in the social studies curriculum. In this situation, effective curriculum implementation and achievement of the curriculum objectives are hardly possible.

\subsection{Research Question Two B}

How suitable are the instructional strategies that teacher of Social Studies used in teaching Social Studies in secondary schools in Osun State?

To answer this question data collected on the suitability of the instructional strategies that teacher used in teaching Social Studies in secondary schools in Osun State were analysed. The results are as presented in table 4. According to the data presented in table 4 the first observation showed that $18.25 \%$ of the public school teachers used suitable strategies to teach social studies contents while $81.75 \%$ used strategies that were not suitable for the contents. Still on the first observation $14.29 \%$ private school teachers used suitable strategies to teach the contents while $85.71 \%$ used unsuitable strategies. During the second observation $23.81 \%$ of the public school teachers used suitable strategies to teach while $76.19 \%$ used unsuitable strategies. The second observation also showed that $9.02 \%$ private school teachers used suitable strategies to teach their contents while $90.98 \%$ used unsuitable strategies. The third observation showed that $34.13 \%$ of the selected public school teachers used suitable strategies and $65.87 \%$ used unsuitable strategies to teach Social Studies. In the selected private schools $20.30 \%$ of the teachers used suitable strategies and $79.70 \%$ used unsuitable strategies to teach social studies contents. The average percentage of public teachers who used suitable strategies to teach Social Studies was $25.4 \%$ while that of private was $14.53 \%$. In other words, $74.60 \%$ of public and $85.46 \%$ private secondary school teachers of Social Studies are not using suitable strategies to teach the contents of the subject in Osun State.

In line with this finding Abdu-Raheem (2015) asserted that the methods used by qualified teachers are different from those used by non-qualified teachers. The existing situation in Osun State may not give room for the use of suitable instructional strategies because there are more untrained and incompetent teachers doing the work both in public and private schools in the state. Adeyemi (2009) put forward that there are strong 
associations between instructional strategies and students learning outcomes. The use of unsuitable instructional strategies may hinder effective teaching/learning process and finally result to learner's poor academic performance. Since no one instructional strategy is best for all learners at all situations, it is important for teachers to be knowledgeable of various strategies and techniques for making decisions about instruction.

\subsection{Research Question Three}

How available are the instructional materials used in teaching Social Studies in secondary schools in Osun State?

To answer this question data collected on the availability of the instructional materials used in teaching Social Studies in secondary schools in Osun State were analysed. The results are as presented in table 5. For the purpose of this study the recommended instructional materials used in teaching Social Studies were divided into 8 categories. Table 5 showed that in the selected public secondary schools textbooks and real objects were $100 \%$ inadequately available while pictures/photographs, resource person and resource room were $100 \%$ not available. Relevant Electronic Media, Print Media and charts were 51.6\%, 18.3\%, 40.48\% inadequately available and $48.4 \%, 81.7 \%$, and $59.52 \%$ not available respectively. In the selected private secondary schools real objects was $100 \%$ inadequately available while pictures/photographs and resource room were $100 \%$ not available. Textbooks were $97 \%$ inadequately available and $3 \%$ not available, relevant electronic media were $23.3 \%$ inadequately available and $76.7 \%$ not available. Print Media were $39.8 \%$ inadequately available and $60.2 \%$ not available. Charts and resource person were $51.13 \%, 14.3 \%$ inadequately available and $48.87 \%$ and $85.7 \%$ not available respectively.

It can be said that there were inadequate provision of instructional materials in the selected public and private schools in Osun State. And this is a serious problem especially when the focus is to promote retention of the subject matter. In line with the results of this study, Akubue (2010) observed that very few instructional materials were available for teaching Social Studies in secondary schools in Nsukka, Nigeria. Also Lyimo, Too and Kipng'etich (2017) have discovered that textbooks, maps and globes are inadequately available in some secondary schools of Arusha district in Tanzanian. However, the results of this study contradict the findings of Eya and Ureme (2011) which stated that instructional materials were available for teaching Social Studies in junior secondary schools in Enugu State Nigeria. This could be as a result of the instruments used by the authors to collect data for the studies on the availability of instructional materials. Questionnaire was used to collect data for Eya and Ureme (2011) study while observation check list where the researchers went round the schools to see the materials was used to collect data for this study.

\section{CONCLUSION AND RECOMMENDATIONS}

The study concluded that social studies curriculum has not been well implemented in Osun State, Nigeria. There are several issues to be addressed in the implementation of social studies curriculum in the State specifically and Nigeria by extension. The inadequacies in the quantity and quality of teachers, the use of inappropriate instructional strategies and instructional materials in teaching Social Studies demand serious attention of every stakeholder in Osun State. Steven, Eric, and John (2005) agreed that teachers have more impact on student learning than any other factor controlled by school systems. The more the availability of qualify teachers the greater their impact on students achievement. Also, teacher competence could be measured with the instructional strategy(ies) they use to present their subject matter since their success leans much more on their ability to communicate with the students effectively. Similarly, instructional materials are important materials provided in the teaching learning process to clarify point, hold learners attention and help them retain important information. In the situation where instructional materials are not available as recommended by the concerned authorities there may be no effective learning.

In line with the findings and conclusion of this study it is recommendable that government at different levels and private owners of secondary schools should employ qualified trained teachers of Social Studies who could teach different content of the subject with suitable/appropriate strategy(ies) and materials. Also all the stakeholders including parents should endeavour provide necessary instructional materials needed by and for the students to enable them learn the subject effectively and being able to manifest values and virtues they have learnt through the subject.

\section{LIMITATION OF THE STUDY}

The study was limited to investigating teacher's quality, instructional strategies and materials used in the implementation process of social studies curriculum in Osun State. The study did not investigate the validity of the social studies curriculum content in relation to the needs of the society. Also, the issues of sex and location were not examined in this investigation. This study may be replicated in other states of the Nigeria Federation. Also further study could be carried out on the validity of social studies curriculum content in relation to the needs of the society as well as influence of sex and location on the implementation of social studies curriculum in Nigeria. 


\section{REFERENCES}

Abdu-Raheem, B. O. (2015) Teachers' Perception of the Effectiveness of Methods of Teaching Social Studies in Ekiti State, Nigeria. World Journal of Education Vol. 5, No. 2. 32-39

Adeyemi, T. O. (2009) The Effective Distribution of Teachers into Secondary Schools in Ekiti State, Nigeria: A Critical Analysis. Current Research Journal of Social Sciences 1(3): 74-83

Adewuya, A. A. (1992). Historical Development of Social Studies Teaching in Nigeria Secondary Schools. Nigeria: www.nijef.com/march-1992/HISTORICAL-DEVELOPMENT

Ajitoni, S.O and Gbadamosi,. T.V (2012). Effects of service learning and educational trips in Social Studies on primary school pupils' environmental knowledge for sustainable development. Academic Research International, Vol. 2, (2)

Akinlaye, F. A. (1981). Why Social Studies. In: NERC (Ed). The Concept and Scope of Social Studies Education for Schools and Colleges. Yaba, Lagos: Onibonoje Publishers.

Akubue, F. N. (2010) Use of instructional materials for teaching social studies in junior secondary schools. The Nigerian Journal of Research and Production Volume 17 No 1, 1-7.

Aliyu Y. A. (2009).Assessment of the implementation of Social Studies curriculum in primary schools in kano metropolis (unpublished Master Thesis): Ahmadu Bello University, Zaria.

Arisi. R. O. (2011). Social Studies education as a means to national integration and unity in Nigeria. European Journal of Educational Studies 3(3),

Edinyang S. D, Eneji C. O, Tijani O. A. \& Dunnamah, A.Y (2013). Environmental and Social Studies education: A collaborative approach towards building an environmentally friendly society. Educational Research Vol. 4 (3), pp. 222- 226.

Ehindero O. J. (1986). Curriculum foundations and development: first edition. Lagos, Concept Publications Limited.

Eya, P. E. And Ureme, C. M. (2011). Availability and utilization of instructional materials for Social Studies in junior secondary schools in Enugu State. The Nigerian Journal of Research and Production Volume 19 No 1 , pp 1-12.

Ezeuzo, P. U. (2011). Refocusing Social Studies curriculum in junior secondary schools for effective promotion of peace education in Nigeria. Journal of Research and Development, Vol. 2 (1)

Federal Ministry of Education (2003). Education Sector Status Report. Abuja Nigeria, Federal Government of Nigeria.

Federal Republic of Nigeria (2004). National Policy on Education 4th Edition. Nigeria.

Greenwald, R., Hedges, L. V. and Laine, R. D. (1996). The Effect of School Resources on Student Achievement. Review of Educational Research 66 (3): pp. 361-396. In: Policy Studies Associates (Ed.). Tennessee. Washington D.C.: The Center for Public Education.

Guilfoile, L and Delander, B (2014). Six proven practices for effective civic learning. Guidebook by the Education Commission of the States. USA.

Gupta, R. (2000). Effective Teaching: Aspect and Technique. U.S.A.

Ikwumelu, S. N. Bassey, M. E and Oyibe, O. A. (2015). Social Studies Education and the need for value-based education in Nigeria. British Journal of Education, Vol. 3, (11), pp.63-74.

International Labour Organization (2016). Rural teachers in Africa: A report for ILO. Geneva International Labour Office.

Lyimo, N. S., Too, J. K and Kipng'etich, K.J. (2017). Perception of teachers on availability of instructional materials and physical facilities in secondary schools of Arusha District, Tanzania. International Journal of Educational Policy Research and Review Vol.4 (5), pp. 103-112.

Marsh, C. J. (1987). Implementation of a Social Studies Curriculum in an Australian Elementary School. The Elementary School Journal, Vol. 87, No. 4 pp. 475- 486

Muna, F. B. (2006). Generating Learning, a Methodology for Improving the Preparation of Teachers for Basic Education: Implication and Significance of Implementing this Model. Malaysia: International Islamic University.minamo12@yahoo.com

National Center on Early Childhood, Development Teaching and Learning (2011). The Preschool Curriculum Consumer Report. http://eclkc.ohs.acf.hhs.gov/hsl c/tta system/t eaching/practice/docs/curriculumconsumer-report.pdf).

Nmom, O. C.(2011). The Attitudinal Development Of Nigerian Children: The Role Of Social Studies In The $21^{\text {st }}$ Century. African Journal of Education and Technology, Vol. (3), pp. 25-31.

Ogbondah, L (2008). An appraisal of instructional materials used to educate migrant fishermen's children in Rivers State, Nigeria. International Journal of Scientific Research in Education, vol. 1(1), 13-25.

Ojo, A. Z (2017). Assessment of economics curriculum implementation in colleges of education and secondary schools in oyo state. (unpublished Master's Thesis). Obafemi Awolowo University Ile-Ife.

Omolewa, M., (1986). Certificate history of Nigeria. Lagos: Longman Nigeria limited. 
Saglam, H. I. (2011). AN investigation on teaching materials used in Social Studies lesson. The Turkish Online Journal of Educational Technology volume 10 Issue 1,1-9

Steven G. Rivkin, Eric A. Hanushek, and John F. Kain, (March 2005) "Teachers, Schools, and Academic Achievement," Econometrica, Vol. 73, (2)

Stufflebeam, D. L. (2003). The CIPP model for evaluation. In D. L. Stufflebeam \& T. Kellaghan (Eds.), The international handbook of educational evaluation (Chapter 2). Boston, MA: Kluwer Academic Publishers.

Stufflebeam, D. L., \& Shinkfield, A. J. (2007). Evaluation theory, models, \& applications. San Francisco, CA: Jossey-Bass.

Subair, S. T \& Talabi, R. B. (2015). Teacher Shortage in Nigerian Schools: Causes, Effects and Administrators Coping Strategies. Asia Pacific Journal of Education, Arts and Sciences, Vol. 2 No. 4.

Symeonidis, V. (2015). The status of teachers and the teaching profession a study of education unions' perspectives. Belgium; Education International Research Institute.

The United Nations Educational, Scientific and Cultural Organization, (2006). Education Quality. UNESCO Education.

Ukadike, J. O., \& Iyamu, E. O. S. (2007). Effects of cooperative learning methods and sex of students on social studies achievement in selected secondary schools in south central Nigeria. African Journal of Studies in Education, 3(1), 74-83.

Umudi, A. B (2012 ). Content implementation in junior secondary school social studies in Nigeria. Nigerian Journal of Curriculum and Instruction Volume 20 No 1,

Usulor V. I (2014). Utilization of resources for effective implementation of Social Studies curriculum in junior secondary schools in ebonyi central education zone, ebonyi state, Nigeria. (unpublished M. A. Thesis) University of Nigeria Nsukka, Department of Arts Education.

Zhang, G. Zeller, N. Griffith, R. Metcalf, D. Williams, J. Shea, C. \& Misulis, K. (2011) Using the Context, Input, Process, and Product Evaluation Model (CIPP) as a comprehensive framework to guide the planning, implementation, and assessment of service-learning programs. Journal of Higher Education Outreach and Engagement, Vol. 15 (4), p. 57

Table 1: Data on the Availability of Social Studies Teacher in Some Selected Secondary Schools in Osun State

\begin{tabular}{|c|c|c|c|c|c|c|c|c|}
\hline \multirow{2}{*}{$\begin{array}{l}\text { Local } \\
\text { Government } \\
\text { Area }\end{array}$} & \multicolumn{4}{|c|}{ Public school } & \multicolumn{4}{|c|}{ Private school } \\
\hline & $\begin{array}{l}\text { No of school } \\
\text { where SOS } \\
\text { Teachers are } \\
\text { Available } \\
\text { among the } \\
\text { Selected } \\
\text { Schools }\end{array}$ & $\begin{array}{l}\text { Minimum No } \\
\text { of SOS } \\
\text { Teachers } \\
\text { Expected to be } \\
\text { Available in } \\
\text { the Selected } \\
\text { Schools in } \\
\text { each Local } \\
\text { Govt Area }\end{array}$ & $\begin{array}{l}\text { No } \\
\text { of } \\
\text { Teacl } \\
\text { Avail } \\
\text { in } \\
\text { Selec } \\
\text { Schoc } \\
\text { each } \\
\text { Local } \\
\text { Area }\end{array}$ & $\begin{array}{l}\text { and } \% \\
\text { SOS } \\
\text { hers } \\
\text { lable } \\
\text { ted the } \\
\text { ols in } \\
\text { of the } \\
\text { Govt. }\end{array}$ & $\begin{array}{l}\text { No of } \\
\text { School } \\
\text { where } \\
\text { SOS } \\
\text { Teachers } \\
\text { are } \\
\text { Available } \\
\text { Among } \\
\text { the } \\
\text { Selected } \\
\text { Schools }\end{array}$ & $\begin{array}{l}\text { Minimum No } \\
\text { of SOS } \\
\text { Teachers } \\
\text { Expected to } \\
\text { be Available } \\
\text { in the Selected } \\
\text { Schools in } \\
\text { each Local } \\
\text { Govt Area }\end{array}$ & $\begin{array}{l}\text { No an } \\
\text { Sos } \\
\text { Availa } \\
\text { in the } \\
\text { Schoo } \\
\text { each } \\
\text { Local } \\
\text { Area }\end{array}$ & $\begin{array}{l}\% \text { of } \\
\text { eachers } \\
\text { le } \\
\text { Selected } \\
\text { of the } \\
\text { Govt. }\end{array}$ \\
\hline A & 12 & 45 & 12 & 26.67 & 15 & 45 & 15 & 33.33 \\
\hline B & 15 & 45 & 15 & 33.33 & 15 & 45 & 15 & 33.33 \\
\hline $\mathrm{C}$ & 15 & 45 & 15 & 33.33 & 15 & 45 & 15 & 33.33 \\
\hline $\mathrm{D}$ & 13 & 45 & 13 & 28.89 & 15 & 45 & 15 & 33.33 \\
\hline $\mathrm{E}$ & 15 & 45 & 15 & 33.33 & 14 & 45 & 14 & 31.11 \\
\hline $\mathrm{F}$ & 14 & 45 & 14 & 31.11 & 15 & 45 & 15 & 33.33 \\
\hline G & 15 & 45 & 15 & 33.33 & 15 & 45 & 15 & 33.33 \\
\hline $\mathrm{H}$ & 12 & 45 & 12 & 26.67 & 15 & 45 & 15 & 33.33 \\
\hline I & 15 & 45 & 15 & 33.33 & 14 & 45 & 14 & 31.11 \\
\hline Total & 126 & 405 & 126 & 31.11 & 133 & 405 & 133 & 32.84 \\
\hline
\end{tabular}

Source: Field Survey 2018 
Table 2: Data on the Availability of Social Studies Teacher in Some Selected Secondary

Schools in Osun State

\begin{tabular}{|c|c|c|c|c|}
\hline Qualification of Social Studies & PUBLIC SCHOO & & PRIVATE SCHOOI & \\
\hline Teachers in Osun State & $\begin{array}{l}\text { No of Social } \\
\text { Studies Teachers }\end{array}$ & $\begin{array}{l}\% \text { of Social } \\
\text { Studies Teachers }\end{array}$ & $\begin{array}{l}\text { No of Social } \\
\text { Studies Teachers }\end{array}$ & $\begin{array}{l}\% \text { of Social } \\
\text { Studies Teachers }\end{array}$ \\
\hline \multicolumn{5}{|c|}{ Qualified Social Studies Teacher } \\
\hline NCE Social Studies & 27 & 21.43 & 20 & 15.04 \\
\hline B.Ed Social Studies & 25 & 19.84 & 16 & 12.03 \\
\hline M.Ed Social Studies & 9 & 7.14 & - & - \\
\hline Ph.D Social Studies & 1 & 0.79 & - & - \\
\hline Total Number of Qualified & 62 & 49.21 & 36 & 27.07 \\
\hline \multicolumn{5}{|c|}{ Off-field/Unqualified Social Studies Teacher } \\
\hline NCE & 10 & 7.94 & 28 & 21.05 \\
\hline B.Ed /B.A/B.Sc & 08 & 6.35 & 19 & 14.29 \\
\hline M.Ed/M.A/M.Sc. & 8 & 6.35 & - & - \\
\hline Ph.D & - & - & - & - \\
\hline OND & 7 & 5.56 & 25 & 18.80 \\
\hline HND & 2 & 1.59 & 10 & 7.52 \\
\hline NYSC & 10 & 7.94 & 15 & 11.28 \\
\hline NPOWER & 19 & 15.10 & - & - \\
\hline $\begin{array}{l}\text { Total Number of Unqualified } \\
\text { Social Studies Teacher }\end{array}$ & 64 & 50.79 & 97 & 72.93 \\
\hline
\end{tabular}

Source: Field Survey 2018

Table 3: Number and Percentage of Teachers that used NERDC Recommended Strategies in Osun State Public and Private Secondary Schools

\begin{tabular}{|c|c|c|c|c|c|c|c|c|c|}
\hline \multirow[b]{2}{*}{$\mathrm{S} / \mathrm{N}$} & \multirow[b]{2}{*}{$\begin{array}{l}\text { Nigerian } \\
\text { Research and Development } \\
\text { Council (NERDC) } \\
\text { Recommended Strategies for } \\
\text { Teaching Social Studies }\end{array}$} & \multicolumn{4}{|c|}{ Pubic } & \multicolumn{4}{|c|}{ Private } \\
\hline & & \multicolumn{2}{|c|}{$\begin{array}{l}\text { No and } \% \text { of } \\
\text { teachers that } \\
\text { used the } \\
\text { strategies }\end{array}$} & \multicolumn{2}{|c|}{$\begin{array}{l}\text { No and \% of } \\
\text { teachers that did } \\
\text { not used the } \\
\text { strategies }\end{array}$} & \multicolumn{2}{|c|}{$\begin{array}{l}\text { No and } \% \text { of } \\
\text { teachers that } \\
\text { used }\end{array}$} & \multicolumn{2}{|c|}{$\begin{array}{l}\text { No and } \% \text { of } \\
\text { teachers that } \\
\text { did not used } \\
\text { the strategies }\end{array}$} \\
\hline 1 & Expository strategy & 126 & $100 \%$ & - & $00 \%$ & 133 & $100 \%$ & - & $00 \%$ \\
\hline 2 & Lecturing strategy & 5 & $3.96 \%$ & 121 & $96.03 \%$ & - & $00 \%$ & 133 & $100 \%$ \\
\hline 3 & Demonstration strategy & 8 & $6.34 \%$ & 118 & $93.65 \%$ & 43 & $32.33 \%$ & 90 & $67.67 \%$ \\
\hline 4 & Discussion strategy & - & $00 \%$ & 126 & $100 \%$ & 1 & $0.75 \%$ & 132 & $99.23 \%$ \\
\hline 5 & Role play strategy & - & $00 \%$ & 126 & $100 \%$ & - & $00 \%$ & 133 & $100 \%$ \\
\hline 6 & Questioning strategy & 57 & $45.24 \%$ & 69 & $54.76 \%$ & 65 & $48.87 \%$ & 68 & $51.13 \%$ \\
\hline 7 & Guided learning strategy & - & $00 \%$ & 126 & $100 \%$ & - & $00 \%$ & 133 & $100 \%$ \\
\hline 8 & Play way strategy & 5 & $3.96 \%$ & 121 & $96.03 \%$ & - & $00 \%$ & 133 & $100 \%$ \\
\hline 9 & Dramatization strategy & 5 & $3.96 \%$ & 121 & $96.03 \%$ & - & $00 \%$ & 133 & $100 \%$ \\
\hline 10 & Inquiry strategy & 34 & $27.2 \%$ & 92 & $73.02 \%$ & 21 & $15.79 \%$ & 112 & $84.21 \%$ \\
\hline 11 & Project strategy & - & $00 \%$ & 126 & $100 \%$ & - & $00 \%$ & 133 & $100 \%$ \\
\hline 12 & Blended learning strategy & - & $00 \%$ & 126 & $100 \%$ & - & $00 \%$ & 133 & $100 \%$ \\
\hline 13 & Field Trip strategy & - & $00 \%$ & 126 & $100 \%$ & 10 & 7.52 & 123 & $92.48 \%$ \\
\hline 14 & Resource person strategy & - & $00 \%$ & 126 & $100 \%$ & 3 & $2.26 \%$ & 130 & $97.74 \%$ \\
\hline 15 & Debate strategy & - & $00 \%$ & 126 & $100 \%$ & - & $00 \%$ & 133 & $100 \%$ \\
\hline 16 & $\begin{array}{l}\text { Combination of two or more } \\
\text { strategies in one lesson }\end{array}$ & 31 & $24.6 \%$ & 95 & $75.40 \%$ & 3 & $2.26 \%$ & 130 & $97.74 \%$ \\
\hline
\end{tabular}

Source: Field Survey 2018 
Table 4: Number and Percentage of Teacher that used Suitable Instructional Strategies as Observed during Social Studies Lessons

\begin{tabular}{|c|c|c|c|c|c|c|c|c|}
\hline & \multicolumn{4}{|c|}{ Public } & \multicolumn{4}{|c|}{ Private } \\
\hline & \multicolumn{2}{|c|}{ No of teacher that } & \multicolumn{2}{|c|}{ No of teacher that } & \multicolumn{2}{|c|}{ No of teacher that } & \multicolumn{2}{|c|}{ No of teacher that did } \\
\hline & $\begin{array}{l}\text { use } \\
\text { stra }\end{array}$ & Suitable & $\begin{array}{l}\text { did } \\
\text { Suit }\end{array}$ & $\begin{array}{l}\text { not used } \\
\text { e strategies }\end{array}$ & $\begin{array}{l}\text { used } \\
\text { strate }\end{array}$ & Suitable & $\begin{array}{l}\text { not } \\
\text { strateg }\end{array}$ & Suitable \\
\hline First observation & 23 & $18.25 \%$ & 103 & $81.75 \%$ & 19 & $14.29 \%$ & 114 & $85.71 \%$ \\
\hline Second observation & 30 & $23.81 \%$ & 96 & $76.19 \%$ & 12 & $9.02 \%$ & 121 & $90.98 \%$ \\
\hline Third observation & 43 & $34.13 \%$ & 83 & $65.87 \%$ & 27 & $20.30 \%$ & 106 & $79.70 \%$ \\
\hline Average & 32 & $25.4 \%$ & 94 & $74.60 \%$ & 19.33 & $14.53 \%$ & 113.66 & $85.46 \%$ \\
\hline
\end{tabular}

Source: Field Survey 2018

Table 5: Data on the Instructional Materials used in Teaching Social Studies in Secondary Schools in Osun State

\begin{tabular}{|c|c|c|c|c|c|c|}
\hline \multirow[b]{2}{*}{$\mathrm{S} / \mathrm{N}$} & \multirow[b]{2}{*}{ ITEM } & \multirow[b]{2}{*}{ Available for Teacher } & \multicolumn{2}{|c|}{ PUBLIC } & \multicolumn{2}{|c|}{ PRIVATE } \\
\hline & & & $\mathrm{N}$ & $\%$ & $\mathrm{~N}$ & $\%$ \\
\hline \multirow[t]{3}{*}{1} & Textbook & Adequately available & - & - & - & - \\
\hline & & Inadequately available & 126 & 100 & 129 & 97 \\
\hline & & Not available & - & - & 4 & 3.0 \\
\hline \multirow[t]{3}{*}{2} & Real Objects & Adequately available & - & - & - & - \\
\hline & & Inadequately available & 126 & 100 & 133 & 100 \\
\hline & & Not available & - & - & - & - \\
\hline \multirow[t]{3}{*}{3} & Pictures/ & Adequately available & - & - & - & - \\
\hline & Photographs & Inadequately available & - & - & - & - \\
\hline & & Not available & 126 & 100 & 133 & 100 \\
\hline \multirow[t]{3}{*}{4} & Relevant Electronic & Adequately available & - & - & - & - \\
\hline & Media & Inadequately available & 65 & 51.6 & 31 & 23.3 \\
\hline & & Not available & 61 & 48.4 & 102 & 76.7 \\
\hline \multirow[t]{3}{*}{5} & Relevant & Adequately available & - & - & - & - \\
\hline & Media & Inadequately available & 23 & 18.3 & 53 & 39.8 \\
\hline & & Not available & 103 & 81.7 & 80 & 60.2 \\
\hline \multirow[t]{3}{*}{6} & Charts & Adequately available & - & - & - & - \\
\hline & & Inadequately available & 51 & 40.48 & 68 & 51.13 \\
\hline & & Not available & 75 & 59.52 & 65 & 48.87 \\
\hline \multirow[t]{3}{*}{7} & Resource Person & Adequately available & - & - & - & - \\
\hline & & Inadequately available & - & - & 19 & 14.3 \\
\hline & & Not available & 126 & 100 & 114 & 85.7 \\
\hline \multirow[t]{3}{*}{8} & Resource Room & Adequately available & - & - & - & - \\
\hline & & Inadequately available & - & - & - & - \\
\hline & & Not available & 126 & 100 & 133 & 100 \\
\hline
\end{tabular}

Source: Field Survey 2018

\section{ACKNOWLEDGEMENTS}

My profound appreciation is expressed to the professionals in the field of tests and measurements whose expert judgements enabled the successful completion of this study. My gratitude is also expressed to all research assistance, the principals, teachers and students of all the selected secondary schools for their cooperation and assistance rendered in the process of collecting data for this study. I appreciate every author whose literature was used in this work.

\section{A BRIEF BIOGRAPHY OF THE AUTHOR}

OBADIORA, Adebayo Joseph (Ph.D) is a lecturer in the Department of Arts and Social Science Education, Obafemi Awolowo University, Ile-Ife, Nigeria. He has his first degree in Social Studies Education, second and third degree in Curriculum Development. Obadiora is working hard and making remarkable contributions in the areas of research through scholarly publications in reputable national and international journals. His research focuses on curriculum development, implementation, assessment and innovation. Other areas of interest include Environmental Education, Peace Education, Community Development and Hygienic Culture. He is a member of professional bodies such as Ife School Curriculum Improvement Group, Social Studies Association of Nigeria (SOSAN), Teacher Registration Council of Nigeria (TRCN). Obadiora A. J. is the General Coordinator of Population Welfare and Empowerment Foundation (POWEF). 